\title{
THE DISTRIBUTION OF QUINIDINE IN HUMAN BLOOD
}

\author{
I.E. HUGHES \& K.F. ILETT \\ Department of Pharmacology, The University of Western Australia, Perth Medical Centre, \\ Western Australia 6008
}

\author{
L.B. JELLETT \\ Departments of Pharmacology and Medicine, The University of Western Australia, Perth Medical Centre, \\ Western Australia 6008
}

1 The uptake of quinidine by washed human red blood cells from isotonic buffer solution (pH 7.4) occurred rapidly and was proportional to the concentration of drug in buffer. A constant red cell/buffer partition ratio of $4.16 \pm 0.15$ s.e. mean was found.

2 Uptake from buffer solution was not affected by temperature or ouabain or by gassing with nitrogen or carbon monoxide and there was no evidence of saturability. Drug in red blood cells was associated largely with the cell contents $(94.4 \pm 1.5 \%$ s.e. mean) following partition.

3 Plasma reduced the uptake of quinidine so that a red cell/plasma partition ratio of $0.82 \pm 0.09$ s.e. mean was found.

4 Alteration of plasma binding by dilution of plasma with buffer showed that uptake was proportional to free drug concentration.

5 The possibility of red cell uptake of drug should be included in any considerations concerning pharmacokinetic aspects of drug action in the body.

\section{Introduction}

Measurement of plasma levels of drugs has become a valuable aid in the management of selected patients (Koch-Weser, 1972) and it is generally appreciated that these plasma levels must be interpreted in conjunction with estimates of plasma binding. Such measurements have been used correctly to determine the pharmacologically active concentration of free drug in the plasma. They have also been used in the calculation of various kinetic parameters such as clearance, rate constant of elimination and volume of distribution. However, little attention has been paid to possible red cell uptake in the calculation of these parameters.

Previous studies with propranolol (Evans \& Shand, 1973; Evans, Nies \& Shand, 1973; Jellett \& Shand, 1973) and diphenylhydantoin (Kurata \& Wilkinson, 1974) have shown that uptake of drug by the red cell is considerable and is a function of drug plasma binding in that only free drug diffuses into the red cell. Therefore the derivation of kinetic parameters from measurements of plasma levels in the absence of a consideration of red cell uptake can only lead to spurious results. The use of such derived parameters in the determination of a patient's therapeutic regime could, therefore, be a cause of incorrect dosage. In addition, the red cell/plasma partition ratio of drug has been shown to have potential significance as a rapid screening technique for plasma binding of therapeutic agents in routine clinical blood samples (Jellett \& Shand, 1973; Kurata \& Wilkinson, 1974).

It is with considerations such as these that we have employed quinidine as a model drug to investigate further the characteristics of red cell/plasma partition of drug and its possible consequences.

\section{Methods}

\section{Preparation of red blood cells}

Fresh heparinized blood was obtained from consenting normal volunteers (aged 21-41 years) who had fasted for $12 \mathrm{~h}$ and the following procedures were then carried out at $4^{\circ} \mathrm{C}$. The blood was centrifuged, plasma and buffy layers were removed and the red cells were washed three times with isotonic phosphate buffer $\left(\mathrm{K}_{2} \mathrm{HPO}_{4}\right.$ 1.41; $\mathrm{NaH}_{2} \mathrm{PO}_{4} \quad 0.26 ; \mathrm{NaCl} 8.10 \mathrm{~g} / 1: \mathrm{pH} \mathrm{7.4)}$. Packed red cells were obtained following a final 
centrifugation at $1200 \mathrm{~g}$ for $10 \mathrm{~min}$ and were then resuspended in either plasma, the above isotonic phosphate buffer or plasma diluted with this buffer and incubated at $37^{\circ} \mathrm{C}$ for 15 minutes. Quinidine, usually in a volume of $0.1 \mathrm{ml}$, was then added to quantities of the suspensions varying between 10 and $40 \mathrm{ml}$. Following a further period of incubation and gentle mixing at $37^{\circ} \mathrm{C}(15 \mathrm{~min}$ unless otherwise specified), the haematocrit was measured. The relative components of the suspension were such that the haematocrit was usually within the range of 42 to $45 \%$ which falls within the normal limits for both male and female human blood. The samples were then centrifuged at $1200 \mathrm{~g}$ for $10 \mathrm{~min}$ and the supernatant was removed and assayed for quinidine. All concentrations are expressed in terms of quinidine sulphate dihydrate.

\section{Quinidine assay}

Plasma, buffer or plasma dilutions in buffer were assayed for quinidine according to the fluorimetric technique of Cramér \& Isaksson (1963) with minor modifications. In all cases, plasma and buffer blanks were carried through the procedure. Briefly, samples $(0.9 \mathrm{ml})$ were alkalinized with $0.5 \mathrm{~N}$ sodium hydroxide $(0.1 \mathrm{ml})$ and extracted with benzene $(5.0 \mathrm{ml})$. After shaking and centrifugation, the organic phase $(3.0 \mathrm{ml})$ was extracted with $0.1 \mathrm{~N}$ sulphuric acid $(3.0 \mathrm{ml})$ and the benzene layer was removed. The fluorescence of the aqueous phase was measured in an Aminco Bowman spectrophotofluorometer (excitation $350 \mathrm{~nm}$, emission $450 \mathrm{~nm}$, slit arrangement 3). The relationship between quinidine concentration and fluorescence was linear over the range $16 \mathrm{ng} / \mathrm{ml}$ to $25 \mu \mathrm{g} / \mathrm{ml}$. This double-extraction method essentially extracts quinidine and dihydroquinidine (Härtel \& Harjanne, 1969; Kessler, Lowenthal, Warner, Gibson, Briggs \& Reidenberg, 1974)

Having measured the concentration of quinidine in supernatant plasma for example, the red cell (RBC)/ plasma (P) drug concentration ratio was determined from the haematocrit $(\mathrm{H})$ and the blood (B)/ plasma ratio according to the following equation which is applicable at a given total plasma concentration according to mass balance considerations:

$$
\frac{\mathrm{RBC}}{\mathbf{P}}=\frac{\mathrm{B} / \mathrm{P}-(1-\mathrm{H})}{\mathbf{H}}
$$

(Equation 1)

An identical relationship also exists for red cells suspended in buffer or varying dilutions of plasma, so that ' $B$ ' also refers to the known concentration of quinidine in the appropriate red cell suspension and ' $P$ ' represents the drug concentration in the resultant supernatant solution.

\section{Measurement of plasma binding}

Binding of quinidine to plasma, buffer or other supernatant dilutions of plasma was determined by equilibrium dialysis. Cellulose dialysis tubing (A.H. Thomas \& Co., Cat. No. 3787-D22) was soaked in distilled water initially at $99^{\circ} \mathrm{C}$ and later in cold distilled water for $4 \mathrm{~h}$ prior to use. A sample $(3.0 \mathrm{ml})$ containing quinidine was placed in a dialysis bag before sealing in an apparatus similar to that employed by Anton (1960) and was then dialysed to equilibrium against $10 \mathrm{ml}$ of isotonic phosphate buffer $\left(\mathrm{K}_{2} \mathrm{HPO}_{4} \quad 14.11 ; \mathrm{KH}_{2} \mathrm{PO}_{4} 2.59\right.$; $\mathrm{NaCl} 1.99 \mathrm{~g} / 1: \quad \mathrm{pH} 7.4)$. Kanamycin sulphate $(10 \mu \mathrm{g} / \mathrm{ml})$ was incorporated in the external buffer solution to prevent bacterial growth. Preliminary experiments had shown that this antibiotic did not interfere with quinidine binding. Control experiments also indicated that binding of quinidine to the dialysis bag was negligible.

\section{Factors determining red cell uptake from buffer}

Red cell uptake of quinidine was investigated using red cells reconsituted in buffer at $37^{\circ} \mathrm{C}$ as outlined previously. In five experiments the effect of varying the incubation time between 5 and $60 \mathrm{~min}$ was investigated. In order to delineate further the time period of red cell uptake, the oil/water partition coefficient of quinidine was measured in seven experiments by the method of Schanker, Nafpliotis \& Johnson (1961). In these studies partition was determined at $37^{\circ} \mathrm{C}$, ethyl acetate being employed as the organic phase and isotonic phosphate buffer (pH 7.4) as the aqueous phase. The effects of concentration (four experiments), temperature (six experiments) ouabain (six experiments) and gassing with nitrogen or carbon monoxide (six experiments) on the uptake of quinidine were also investigated. The consequences of varying plasma drug binding in relation to red cell uptake of quinidine were examined in four experiments in which plasma binding had been progressively reduced by dilution of the plasma with buffer prior to suspending the red cells and adding quinidine.

\section{Distribution of quinidine in red blood cells}

In this group of experiments, it was necessary to obtain suspensions of red cell contents after quinidine had been allowed to distribute between the intact cells and buffer. Previous investigators have lysed red cells by the addition of hypotonic buffer (Dodge, Mitchell \& Hanahan, 1963). 
However, mixing of the red cells with additional buffer may alter the distribution of quinidine already in the cells. Accordingly, in the present study, red cells were lysed by homogenization (Ultra-Turrax blender, Model TP18-10N) at $4^{\circ} \mathrm{C}$. Preliminary experiments had demonstrated that this technique was as effective as that employing hypotonic buffer, in that both produced virtually $100 \%$ lysis of red cells.

In five experiments, duplicate aliquots of packed red cells which had been previously suspended and incubated at $4^{\circ} \mathrm{C}$ in a buffer solution with added quinidine, were homogenized at the same temperature for 2 minutes. The homogenate was centrifuged at $1200 \mathrm{~g}$ for $10 \mathrm{~min}$ to remove any residual red cells. The supernatant (containing red cell membranes and cell contents) was sampled and assayed for quinidine. The remaining supernatant was then centrifuged at $20,000 \mathrm{~g}$ for $1 \mathrm{~h}$ at $4^{\circ} \mathrm{C}$ in order to sediment the cell membranes and this supernatant was then assayed for quinidine. The concentration of quinidine in the high-speed supernatant solution was expressed as a percentage of that in the low speed supernatant solution.

\section{Expression of results}

All results are expressed as mean \pm s.e. mean and Student's $t$-test was used to evaluate statistical significance.

\section{Drugs}

The following drugs were used: quinidine sulphate B.P.; ouabain, B.P.; lithium heparin (Calbiochem.).

\section{Results}

Preliminary experiments showed good total recoveries $(96 \pm 1 \% ; n=7)$ of quinidine from plasma or buffer suggesting that the drug was not metabolised by plasma. In addition, the concentra-

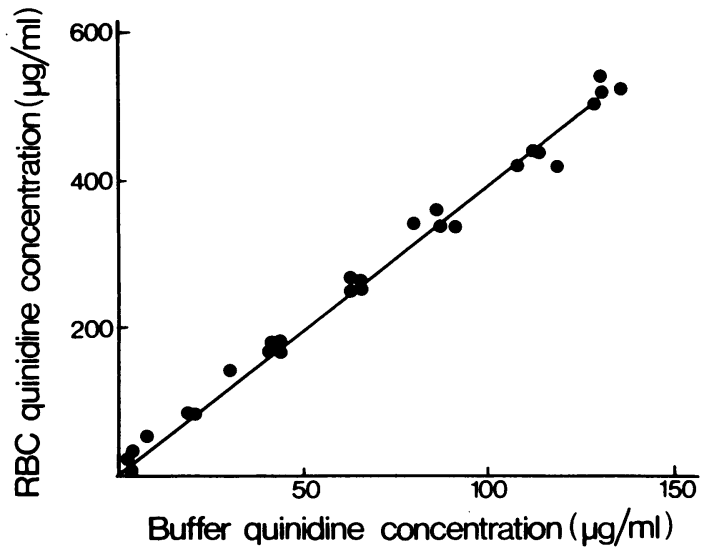

Figure 1 Effect of concentration on the uptake of quinidine by red cells suspended in buffer solution. The data represent four experiments and the line fitted by least squares regression analysis is described by $y=4.528+3.909 \times(r=0.99)$.

tion of quinidine in the red cell did not alter with incubation from 5 to $60 \mathrm{~min}$ (Table 1) indicating that red cell metabolism of quinidine was unlikely over this period of time. Other studies investigating the effect of incubation time on the red cell uptake of quinidine from plasma or buffer (Table 1), indicated that uptake was unaffected by the incubation period over the range of 5-60 min and $15 \mathrm{~min}$ was selected for all subsequent studies. Such a rapid equilibration time was expected as the mean value of the oil (ethyl acetate)/water partition coefficient for quinidine was $8.05 \pm 0.08$ at $\mathrm{pH} 7.4$ and $37^{\circ} \mathrm{C}$. This result corresponds with a rapid rate of drug penetration into red cells (Schanker et al., 1961).

The uptake of quinidine by red cells from buffer solutions in which binding was essentially absent showed a linear relationship to drug concentration (Figure 1) and the process did not demonstrate any evidence of saturability up to initial quinidine concentration of $300 \mu \mathrm{g} / \mathrm{ml}$. The

Table 1 Effect of time on the uptake of quinidine by red cells from plasma and buffer. The values shown (mean \pm s.e. mean) represent data from five subjects and the respective concentrations are expressed as $\mu \mathrm{g} \mathrm{drug} / \mathrm{ml}$ plasma or buffer. The initial concentration of quinidine was $3.0 \mu \mathrm{g} / \mathrm{ml}$.

$\begin{array}{ll}\text { Plasma } & 3.58 \pm 0.10 \\ \text { RBC } & 2.26 \pm 0.13 \\ \text { RBC/Plasma ratio } & 0.64 \pm 0.06 \\ \text { Buffer } & 1.26 \pm 0.04 \\ \text { RBC } & 5.22 \pm 0.06 \\ \text { RBC/Buffer ratio } & 4.18 \pm 0.20\end{array}$

$3.50 \pm 0.10$
$2.36 \pm 0.13$
$0.68 \pm 0.06$
$1.31 \pm 0.05$
$5.17 \pm 0.08$
$4.00 \pm 0.22$




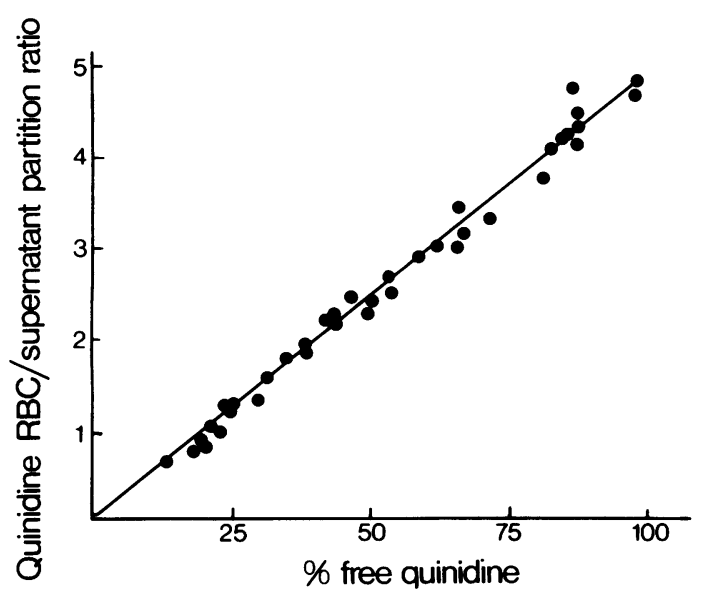

Figure 2 Relationship between the percentage of free quinidine estimated by equilibrium dialysis and the calculated $\mathrm{RBC}$ /supernatant partition ratio. The data were obtained by dilution of plasma from four subjects. The line is represented by $y=0.055+0.048 x$ $(r=0.99)$.

red cell uptake of drug from buffer was not affected by ouabain $(1 \mu \mathrm{M})$, by temperature reduction to $4^{\circ} \mathrm{C}$, nor by gassing with nitrogen or carbon monoxide (Table 2). Quinidine taken up by the red cells was largely associated with the red cell contents $(94.4 \pm 1.5 \%)$ rather than the cell membranes.

\section{Uptake by red blood cells and the effect of plasma binding}

Quinidine accumulated in red cells which had been suspended in buffer (red cell/buffer ratio $4.16 \pm 0.15 ; n=8)$, however, the presence of plasma considerably reduced red cell uptake (red cell/plasma ratio $0.82 \pm 0.09 ; n=8)$. These data and the relative constancy of the red cell/buffer partition ratio between different normal individuals suggested that plasma binding of drug diminished red cell uptake by reducing the concentration of free drug. Confirmation of this hypothesis was provided by the experiments in which plasma binding was decreased by dilution of plasma with buffer. There was a linear relationship between the percentage of free quinidine determined by equilibrium dialysis and the calculated red cell/supernatant drug partition ratio (Figure 2), confirming that quinidine was taken up by red cells as a linear function of free drug concentration.

\section{Normal plasma binding of quinidine}

Binding of quinidine at a concentration of $3.0 \mu \mathrm{g} / \mathrm{ml}$ in plasma was measured at $37^{\circ} \mathrm{C}$ in sixteen normal persons and was found to be $85.3 \pm 1.2 \%$ (range $76.1-92.2 \%$ ).

\section{Discussion}

Quinidine is taken up by human red cells as a function of the concentration gradient for free drug which is in turn dependent on the extent of quinidine binding in the plasma. The partition coefficient expressed by the red cell/plasma free drug concentration is relatively constant between different normal individuals. It appears that the red cell uptake of quinidine represents a passive partition of free drug between plasma and cells. This is shown by the absence of any effect on uptake of changes in temperature, inhibition of cellular enzymes with nitrogen, inhibition of the membrane sodium-potassium ATPase pump mechanism with ouabain, or the formation of carboxy-haemoglobin by means of carbon monoxide. In addition, the uptake process was not saturable up to extremely high initial concentrations of quinidine.

The relative constancy of the red cell/plasma free drug partition coefficient between normal individuals has been suggested as a rapid method for determining free drug concentration (Jellett \& Shand, 1973; Kurata \& Wilkinson, 1974). This has application to the rapid assessment of plasma binding of drug and the screening of abnormal binding during the therapeutic monitoring of plasma drug concentrations (Borondy, Dill, Chang, Buchanan \& Glazko, 1973; Jellett \& Shand, 1973; Kurata \& Wilkinson, 1974).

These earlier studies applied such principles to either diphenylhydantoin or propranolol. The

Table 2 Effect of nitrogen, carbon monoxide, ouabain $(1 \mu \mathrm{M})$ and temperature on the red cell uptake of quinidine in six experiments using blood from different donors. The values of the RCB/Buffer partition ratios shown represent the mean \pm s.e. mean. The initial concentration of quinidine was $3.0 \mu \mathrm{g} / \mathrm{ml}$.

$\begin{array}{lccccc} & \text { Air (control) } & N_{2} & \text { CO } & \text { Ouabain } & 4^{\circ} C \\ \begin{array}{lcccc}\text { RBC/Buffer ratio } \\ t \text {-test (against control) }\end{array} & 4.31 \pm 0.20 & \begin{array}{c}4.15 \pm 0.23 \\ P>0.6\end{array} & \begin{array}{c}4.29 \pm 0.15 \\ P>0.9\end{array} & \begin{array}{c}4.35 \pm 0.19 \\ P>0.8\end{array} & \begin{array}{c}4.03 \pm 0.23 \\ P>0.3\end{array}\end{array}$


present quinidine study has elicited similar findings which suggest that red cell partition with free drug is a general phenomenon. Changes in plasma free drug produced by plasma dilution do not affect the red cell/plasma free drug partition ratio so that reduction in plasma binding of drug elicits predictable changes in the total red cell/plasma partition ratio. This has clinical significance in relation to free drug partition ratio between plasma and red cells in disease-states associated with low plasma protein levels, such as cirrhosis of the liver or chronic renal failure.

In contrast to plasma assay of drug, the direct assay of red cell content of drug is usually difficult and often inaccurate. Direct measurement of the total red cell/plasma partition ratio may accord ingly be an unreliable estimate. A better method is to determine the patient's total blood/plasma partition ratio by direct assay. Measurement of the whole blood haematocrit which has an entirely predictable influence on the blood/plasma ratio (Kurata \& Wilkinson, 1974) and subsequent application to equation 1 then allows accurate calculation of the total red cell/plasma partition ratio. From standard curves relating the red cell/plasma ratio to per cent free drug as derived

\section{References}

ANTON, A.H. (1960). The relation between the binding of sulfonamides to albumin and their antibacterial efficacy. J. Pharmac. exp. Ther., 129, 282-290.

BORONDY, P., DILL, W.A., CHANG, T., BUCHANAN, R.A. \& GLAZKO, A.J. (1973). Effect of protein binding on the distribution of 5,5-diphenylhydantoin between plasma and red cells. Ann. N.Y. Acd. Sci., 226, 82-87.

CRAMÉR, G. \& ISAKSSON, B. (1963). Quantitative determination of quinidine in plasma. Scand. J. clin. Lab. Invest., 15, 553-556.

DODGE, J.T., MITCHELL, C. \& HANAHAN, D.J. (1963). The preparation and chemical characteristics of hemoglobin-free ghosts of human erythrocytes. Arch. Biochem. Biphys., 100, 119-130.

EVANS, G.H., NIES, A.S. \& SHAND, D.G. (1973). The disposition of propranolol. III. Decreased half-life and volume of distribution as a result of plasma binding in man, monkey, dog and rat. J. Pharmac. exp. Ther., $186,114-122$.

EVANS, G.H. \& SHAND, D.G. (1973). Disposition of propranolol. VI. Independent variation in steady-state circulating drug concentrations and half-life as a result for propranolol and diphenylhydantoin in normal individuals (Jellett \& Shand, 1973; Kurata \& Wilkinson, 1974) per cent binding, per cent free drug and actual plasma free drug concentration may be determined. The advantage of these screening techniques is that large numbers of patients' samples can be screened and only those with variant binding need to undergo the prolonged and more tedious equilibrium dialysis method of measuring plasma binding.

Not only can partition of drug between plasma and red cell be used in the manner outlined above, but it should be emphasized that the calculation of various pharmacokinetic parameters such as rate constant of elimination, volume of distribution or estimates of clearance derived from these parameters is only valid in the absence of significant red cell uptake. Furthermore, the red cell may provide a reservoir of drug which could contribute to drug-drug interactions of the displacement type. Application of drug plasma levels to patient therapy may therefore be inadequate without due consideration of the role of the red cell.

We wish to express our appreciation to our blood donors. Reprint requests should be addressed to L.B.J. of plasma drug binding in man. Clin. Pharmac. Ther., 14, 494-500.

HÄRTEL, G. \& HARJANNE, A. (1969). Comparison of two methods for quinidine determination and chromatographic analysis of the difference. Clin. chim. Acta, 23, 289-294.

JELLETT, L.B. \& SHAND, D.G. (1973). Uptake of propranolol by washed human red blood cells. The Pharmacologist, 13, 245.

KESSLER, K.M., LOWENTHAL, D.T., WARNER, H., GIBSON, T., BRIGGS, W. \& REIDENBERG, M.M. (1974). Quinidine elimination in patients with congestive heart failure or poor renal function. New Engl. J. Med., 290, 706-709.

KOCH-WESER, J. (1972). Serum drug concentrations as therapeutic guides. New Engl. J. Med., 287, 227-231.

KURATA, D. \& WILKINSON, G.R. (1974). Ery throcy te uptake and plasma binding of diphenylhydantoin. Clin. Pharmac. Ther., 16, 355-362.

SCHANKER, L.S., NAFPLIOTIS, P.A. \& JOHNSON, J.M. (1961). Passage of organic bases into human red cells. J. Pharmac. exp. Ther., 133, 325-331.

(Received March 3, 1975) 